\title{
Tuberculosis of the parotid gland in an eight year old boy
}

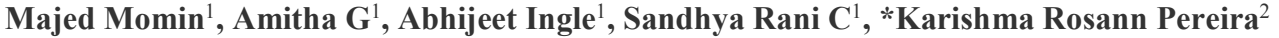

Sri Lanka Journal of Child Health, 2017; 46(3): 293-294

DOI: http://dx.doi.org/10.4038/sljch.v46i3.8338

(Key words: Extra-pulmonary tuberculosis, parotid gland, fine needle aspiration cytology)

\section{Introduction}

Parotid tuberculosis (TB) is a rare form of extrapulmonary $\mathrm{TB}^{1,2}$. We report a case of primary parotid TB in an 8-year-old boy.

\section{Case report}

An 8-year-old boy presented to the Ear, Nose and Throat (ENT) Department of Yashoda hospital, Hyderabad with a swelling in the right preauricular region for one and half months. The swelling was gradual in onset and was associated with an intermittent, dull aching type of pain. There was no history of fever, cough or weight loss. There was no significant past medical or family history. On examination, child was well built and afebrile, with normal vital parameters. There was a right sided pre-auricular swelling $2 \times 2 \mathrm{~cm}$, firm, mobile and non-tender. There was no sinus opening or discharge from swelling. Facial nerve function was normal. A provisional clinical diagnosis of parotid neoplasm was made and fine needle aspiration cytology (FNAC) was done.

The erythrocyte sedimentation rate (ESR) was $40 \mathrm{~mm}$ after the first hour. Screening tests for human immunodeficiency virus (HIV), Hepatitis B surface antigen (HBsAg) and Hepatitis $\mathrm{C}$ virus were negative. Mantoux was negative. Posteroanterior view of the chest radiograph was normal. Ultrasonography of the parotid region revealed a hypoechoic complex mass in the superficial lobe of the right parotid $(20 \times 17 \mathrm{~mm})$ with no necrosis or cystic change suggestive of inflammatory mass or parotid neoplasm. Fine needle aspiration cytology (FNAC) was done from the lesion and scanty, yellowish purulent blood mixed material was aspirated. Haematoxylin and Eosin (H\&E) and May-Grunwald Giemsa (MGG) stained cytosmears revealed epithelioid cell clusters and occasional

${ }^{1}$ Yashoda Hospital, Malakpet, India, ${ }^{2}$ Yashoda Super Speciality Hospitals, India

*Correspondence: karishmarosann@gmail.com

(Received on 24 August 2016: Accepted after revision on 23 September 2016)

The authors declare that there are no conflicts of interest

Personal funding was used for the project.

Open Access Article published under the Creative

Commons Attribution CC-BY cC (i) License giant cells. Nuclear debris and focal areas of caseation necrosis were seen (Figure 1).

Patient was treated with the daily regimen of isoniazid (5 $\mathrm{mg} / \mathrm{kg} /$ day), rifampicin (10 $\mathrm{mg} / \mathrm{kg}$ /day), pyrazinamide (25-35 $\mathrm{mg} / \mathrm{kg} /$ day), and ethambutol $(15-25 \mathrm{mg} / \mathrm{kg} /$ day $)$ for the first 2 months followed by isoniazid and rifampicin for

\section{Discussion}

There are only around 100 cases of parotid TB reported in the literature and most of these have been diagnosed by histology, after parotidectomy ${ }^{1}$. Most of these cases have been in adults but a few cases have been reported in children ${ }^{3,4}$. Parotid TB is usually unilateral but may rarely be bilateral ${ }^{5}$. FNAC has $80 \%$ sensitivity and $93 \%$ specificity for diagnosing parotid $\mathrm{TB}^{6}$. High resolution ultrasound examination can differentiate possible benign from malignant neoplasm and demonstrate whether palpable lesion arises within the parotid gland or are periparotid in location. However they cannot differentiate tuberculous from non-tuberculous lesions ${ }^{7}$. In our patient diagnosis was made by demonstration of epithelioid granulomas and acid fast bacilli using FNAC cytosmears without resorting to histopathological examination after parotidectomy.

\section{References}

1. Janmeja AK, Das SK, Kochhar S, Handa U. Tuberculosis of the parotid gland. Indian Journal of Chest Diseases and Allied Sciences 2003; 45(1):67-9. PMid: 12683715

2. Sethi A, Saren D, Sabherwal A, Malhotra V. Primary parotid tuberculosis: Varied presentations. Oral Diseases 2006; 12(2); 213-15. https://doi.org/10.1111/j.16010825.2005.0 1182.x PMid: 16476047

3. Coen LD. Tuberculosis of the parotid gland in a child. Journal of Pediatric Surgery 1987; 22(4): 367-8. https://doi.org/10.1016/S00223468(87)802 44-0 
4. Borki R, Bouti K, Lahma J, Bouadel N, Rkain I, Nitassi S. Tuberculosis of the parotid gland in children: A report of 4 cases. International Journal of Medicine and Surgery 2015; 2(2). Available from: http://www.mbmj.org/index.php/ijms/artic le/view/78

https://doi.org/10.15342/ijms.v2i2.78

5. Takhar R, Bunkar M, Jungid V, Saxena A. Bilateral parotid gland TB: A rare occurrence. Egyptian Journal of Chest Diseases and Tuberculosis 2015; 64(3): 653-6.

https://doi.org/10.1016/j.ejcdt.2015.03.002
6. Lau SK, Wei WI. Efficacy of fine needle aspiration cytology in the diagnosis of tubercular lymphadenopathy. Journal of Laryngology and Otology 1990; 104:24-7. https://doi.org/10.1017/S00222151001116 97

7. Howlett DC .High resolution ultrasound assessment of the parotid gland British Journal of Radiology 2003; 76:217-7. https://doi.org/10.1259/bjr/33081866 PMid: 12711649
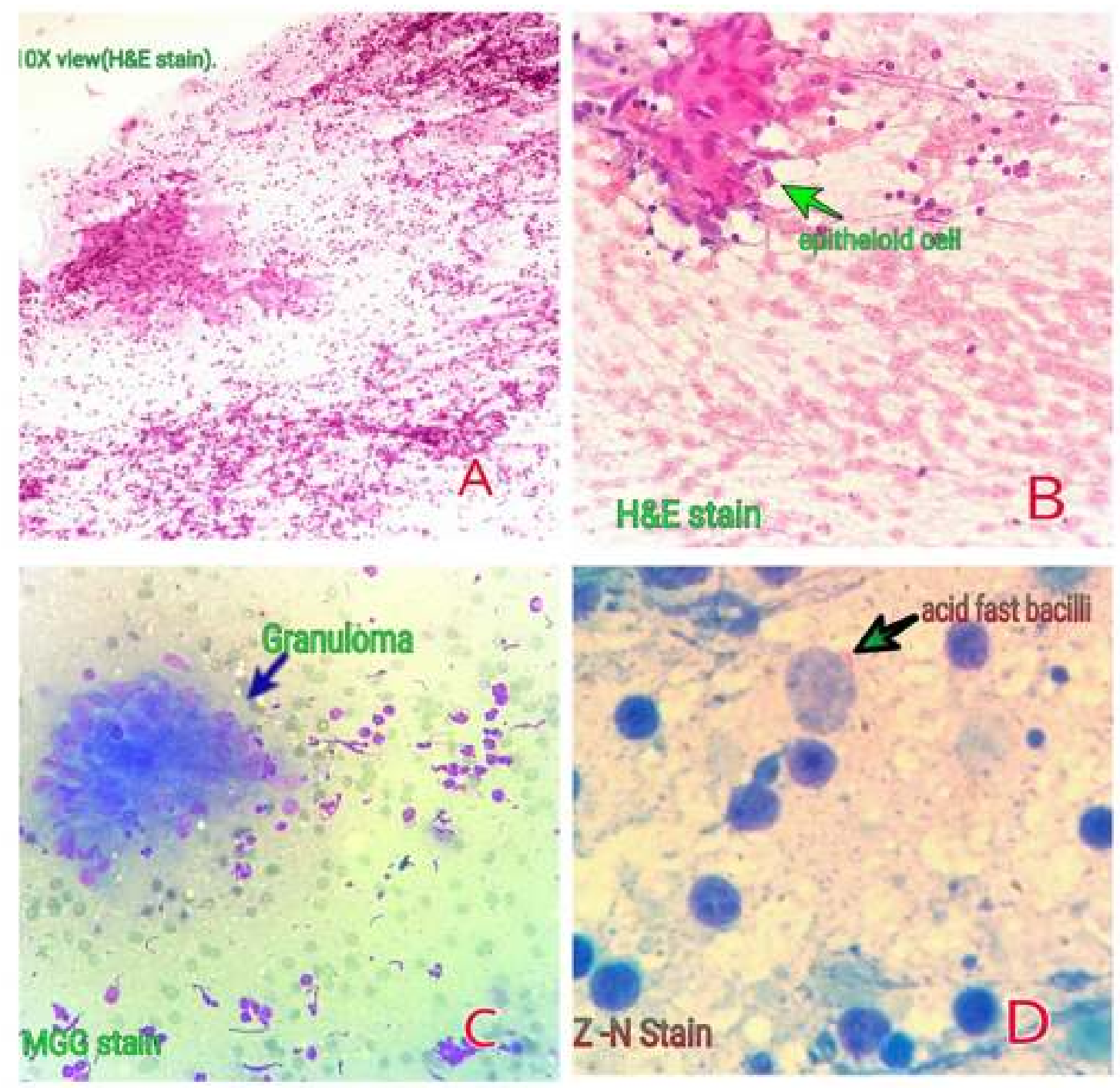

Figure 1: Cytosmears showing epithelioid cells, granuloma and acid fast bacilli 